\title{
JOB CREATION PATTERNS IN THE MALAYSIAN MANUFACTURING SECTOR: DOES TECHNOLOGY MATTER?
}

\author{
Aznita Samsi ${ }^{1 *}$, Siti Nur Fatihah Samsuddin ${ }^{1}$, Norehan Abdullah ${ }^{1}$, Selamah Maamor ${ }^{2}$, \\ Hussin Abdullah ${ }^{1}$, Sabri Nayan ${ }^{1}$ \\ ${ }^{1}$ School of Economics, Finance and Banking, Universiti Utara Malaysia, \\ 06010 Sintok, Kedah DA, Malaysia \\ ${ }^{2}$ Islamic Business School, Universiti Utara Malaysia, 06010 Sintok, Kedah DA, Malaysia
}

(Received: July 2018 / Revised: September 2018 / Accepted: December 2018)

\begin{abstract}
The Malaysian government claims that the implementation of advanced technology in the production process following the Economic Transformation Program (ETP) will create many jobs in the economy. To evaluate this statement, this study calculates the rate of job creation based on the formula developed by Davis and Haltiwanger (1999), plotting and analysing the pattern of job creation in high- and low- technology level sub-sector groups. From the descriptive analysis, both technology groups show distinctive patterns of job creation. Hence, this study provides information to policymakers to enable them to strike a balance between technology and job creation capacity in the manufacturing sector.
\end{abstract}

Keywords: Employment; Labor market; Production performance; Technology; Transformation process

\section{INTRODUCTION}

Malaysia is a nation that has succeeded in encouraging rapid economic growth since its independence in 1957. It has evolved from being an agricultural and commodity-based economy to one that is industry-based. Currently, the country is undergoing a transformation process with the aim to become one of the top 20 countries in terms of economic development, social progress and innovation at the global level (National SME Development Bank Council, 2016). The introduction of the Economic Transformation Program (ETP) by the sixth Malaysian Prime Minister has encouraged the manufacturing sector, as one of the New Key Economic Areas (NKEAs), to re-structure its production method, from a production- based economy (p-economy) to a knowledge-based one (k-economy). One of the techniques in the knowledge-based production process is the use of technology and innovation. Therefore, the restructuring of the production process is expected to greatly increase production in the manufacturing sector, and also lead to a high level of job creation. As the statistics in the Malaysian Manufacturing Sector Survey Report (2015) show, the total workforce in the manufacturing sector in 2014 was $2,096,197$, a figure which is expected to be increase year on year.

In general, the performance of the labor market in the Malaysian manufacturing sector is measured according to employment growth. The pattern of employment growth is used to observe the trends in the size of the labor force in the sector. If employment growth increases,

\footnotetext{
${ }^{*}$ Corresponding author's email: aznita@uum.edu., Tel. +604-9286824, Fax.+ 604-9286752

Permalink/DOI: https://doi.org/10.14716/ijtech.v9i8.2746
} 
this indicates an increase in labor supply in the sector. However, if this growth is negative, it means a decrease in the supply. However, Blanchflower and Burgess (1996) and Davis et al. (1998) suggest that it is inaccurate to explain labor market performance in terms of employment growth. Therefore, they explain the concept of job creation by defining employment growth according to changes in the size of industry.

Such imprecision in explaning labor market performance also occured in the manufacturing sector in Malaysia. Based on Figure 1, it is found that labor market performance is underestimated if it is measured based on employment growth rather than the measurement of job creation. This situation can have an impact on the effectiveness of policies based on the overall labor market, and especially on the labor force.

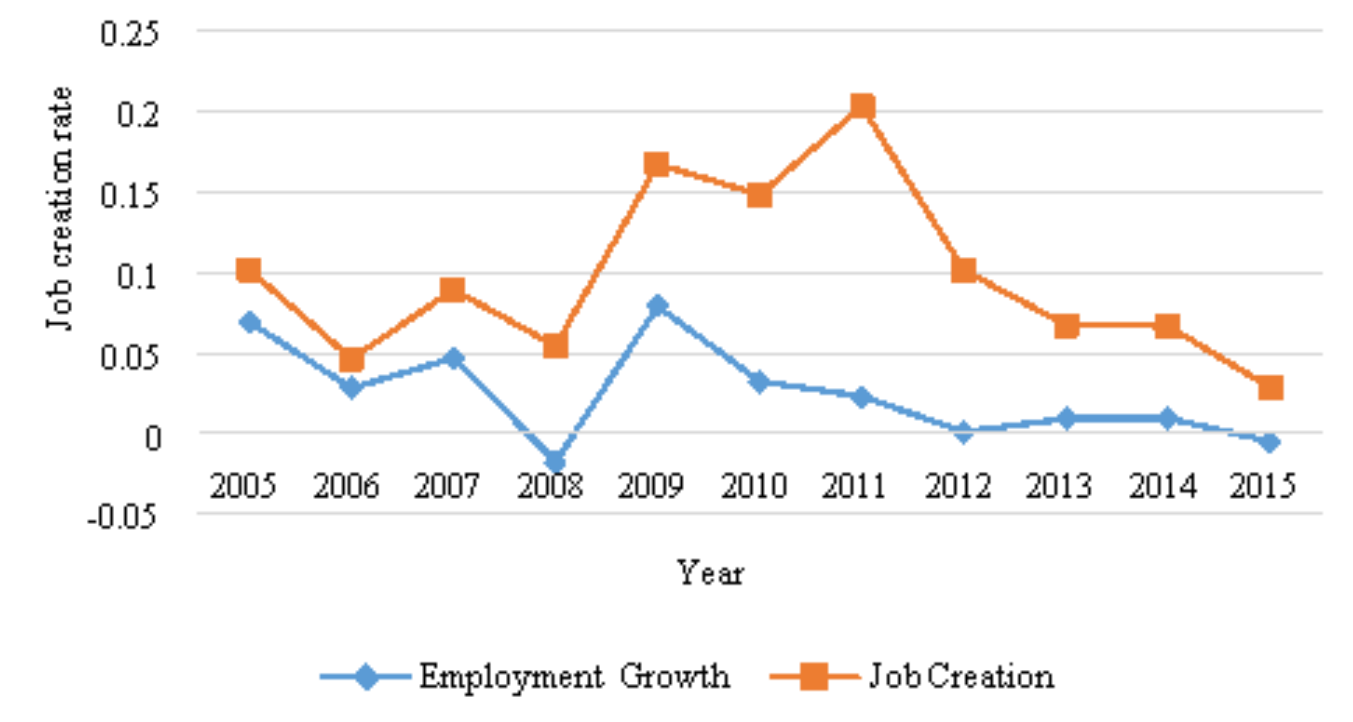

Figure 1 Trend in employment growth and job creation in the Malaysian manufacturing sector (2005-2015)

As noted by Davis and Haltiwanger (1992), it is important to understand the difference between job creation and employment growth. If the job creation pattern is measured by the employment growth pattern, the performance of the labor market will be underestimated. The finding of Davis and Haltiwanger (1992) is supported by Stavrunova (2001), who suggests that the job creation pattern is more appropriate for analysing the performance of the labor market as it demonstrates employers' labor demands, which are normally hidden by the employment growth pattern.

The use of technology in the production process not only affects employment growth, but job creation is also affected. As described in Schumpeter's Creative Destruction theory (Schumpeter, 1961), when technology is used in the production process, it will increase high-skill job creation and lead to low-skill job destruction simultaneously. Nonetheless, only a few previous studies have found significant differences in job creation patterns between different levels of technology; these include works by Piva et al. (2005), Coad and Rao (2007) and Bogliacino and Pianta (2010).

In conclusion, some studies have been conducted related to the job creation pattern, but from the literature reviewed in this field, the researchers have found few studies which analyze the job creation pattern according to technology level. Additionally, it has also been found that studies related to job creation, specifically patterns of job creation in Malaysia or the manufacturing sector, are limited. 
Moreover, most of the previous studies only focus on the role of advanced technology in job creation in developed countries such as Germany and Canada. Meanwhile, few recent studies conducted in developing countries such as Malaysia, Indonesia or China have have explored the role of the level of technology in job creation". Therefore, the core of this study is analysis of the job creation pattern, focusing on the high- and low-technology level sub-sectors in the Malaysian manufacturing sector, with the aim of providing more information of job creation patterns from the perspective of demand for labor.

The lack of reliable job creation patterns hinders practitioners, policymakers and manufacturers from making more accurate forecasts of labor demand trends in the manufacturing sector. Therefore, this study will fill the gap by providing an overview of the performance of the labor market in sub-sectors of Malaysian manufacturing in the portion "in relation to" labor demand. The study also provides information on labor in terms of which sub-sectors in the Malaysian manufacturing sector are currently active in job creation and demand for labor. Moreover, the finding of the study can serve as a guide to policymakers to address the gaps in the labor market information of the Malaysian manufacturing sector.

Historically, the study of the job creation concept can be traced back to Davis and Haltiwanger (1990), and other studies such as those of Albæk and Sørensen (1998), Haltiwanger and Vodopivec (2003) and Hijzen et al. (2010). However, researchers in labor economics often use the term 'job creation' to mean the same as 'employment'. The definition and specific measurement of job creation in the labor economics literature are not clearly stated. The definition and calculation of employment growth is often used in analyzing job creation, whereas employment growth represents the labor supply perspective, while job creation represents the labor demand perspective. To date, this gap has been filled by Davis and Haltiwanger (1990), whose concept of job creation is clearly defined and is accompanied by specific formulas and criteria. However, their study focused on the US manufacturing sector. Subsequently, Van Reenen (1997), Stavrunova (2001) and Kerr et al. (2014) have disputed the concept of employment as workers and jobs as position in firms.

On the other hand, study of job creation patterns has been undertaken in various countries, such as United States, United Kingdom and Canada (Garibaldi, 1998), Slovenia (Bojnec \& Konings, 1999), Ukraine (Stavrunova, 2001), five transition countries Poland, Estonia, Slovenia, Bulgaria and Romania (Faggio \& Konings, 2003) and Australia (Mitchell et al., 2006). These studies used descriptive analysis to analyse the job creation pattern in the respective countries.

Garibaldi (1998) conducted a comparative study to analyse the pattern of job creation in three developed countries, namely the United States, United Kingdom and Canada. The study examined this pattern in response to the economic cycle, using descriptive analysis. It was found that the pattern of job creation in these three countries fulfiled the cyclical criteria of such creation. When the economy is at its peak, the magnitude of job creation is large, while if it is in contraction, job creation will be low. However, Garibaldi (1998) study defines job creation based on employment growth. Thus, the pattern of job creation acquired is based on the measurement of this growth, not the actual calculation of job creation.

In contrast, the research conducted in Australia by Mitchell et al. (2006) used a calculation of job creation to analyze its pattern in accordance with the economic cycle. The method used to achieve the objective of the study was descriptive analysis. Despite the difference in the measurement of job creation, the findings satisfy the cyclical criteria of the job creation pattern, in line with studies conducted in the US, UK and Canada. The job creation rate in Australia was high during economic expansion, but lower when the economy was declining, as was also found by Garibaldi (1998). 
Bojnec and Konings (1999) conducted a study in Slovenia using the descriptive analysis method, examining the pattern of job creation by employing the calculated job creation rate. The study found that at the beginning of the transition process, the pattern of job creation in terms of magnitude was found to be lower than at the end of the process. The study suggests that at the beginning of the transition process, the magnitude of the pattern of job creation was low due to the decline in the demand for labor in state-owned firms. At the same time, the growth of new private firms and de novo firms was too slow to support the economy's transition process.

With contrary findings to the case of Slovenia, a study was made by Jackson and Mach (2009) in Poland covering the period of economic transition from 1988 to 1998 . It used the descriptive analysis method to examine the pattern of job creation in terms of magnitude, based on firm ownership, employing the job creation rate calculated by Davis and Haltiwanger (1999) to plot the pattern of job creation. The results show that the magnitude of job creation in Poland at the beginning of the economic transition process was higher than at the end of the process. At the beginning of the transition process, the results show that there was an increase in demand for labor by private firms and state-owned enterprises. This finding is opposite to those of the earlier studies of Estonia and Slovenia.

According to the augmented labor-demand equation, different technological levels result in different patterns of employment growth. Taking into account employment growth as job creation, different levels of technology also result in different patterns of job creation. A high technology level encourages firms to creates jobs, although in small numbers (Bogliacino \& Vivarelli, 2012)

A study by Bogliacino et al. (2012), using the regression of Least Squares Dummy Variables Corrected (LSDVC), found that the technology level represented by R\&D expenditure was significantly positively related to employment growth. The high technology industrial sector expands its production by creating jobs, but this is irrelevant in the traditional manufacturing sector which possesses a lower technology level.

Said et al. (2012) in thier study have estimated the effect of R\&D expenditure on employment growth as the underlying reason for job creation. The study was conducted on the Malaysian manufacturing sector using dynamic panel data based on Neoclassical Production theory Theory. The regression results of the GMM-System method contradict with previous studies in $2^{\text {nd }}$ lagged result there is a negative significant correlation between $R \& D$ expenditure and employment growth. It is explained that the wide use of $R \& D$ expenditure will reduce labor input in the production process. In other words, $R \& D$ expenditure encourages firms to use modern machines in the production process, which replace the labor input (Said et al., 2012).

Another study by Ciriaci et al. (2016) was conducted to compare the pattern of job growth in innovative and non-innovative firms. Data were collected from 3300 firms in Spain from 2002 to 2009, and semi-parametric regression was used to investigate the correlation between innovations (measured on the basis of the intensity of R\&D expenditure) in a series of job growth over that period. The empirical results of the study show that job creation in innovative firms displayed a persistent pattern throughout the time of the study, but not in non-innovative firms. Therefore, this study suggests that innovation supports and stabilizes the pattern of employment growth in firms.

Besides R\&D expenditure, Kianian et al. (2015) studied the role of Addictive Manufacturing (AM) technologies as an innovation process which affects overall job creation and the types of job creation in the economy. Their study also incorporates wage and product demand in addition to Addictive Manufacturing (AM) technologies and was conducted among the BRIC countries. The results of the study are: (1) AM technologies, as an innovation process, have contributed to job creation in the manufacturing sector positively; (2) AM technologies do not lead to excessive 
job creation in the BRIC countries; (3) AM technologies contribute significantly to job creation related to product development; and lastly (4) AM technologies contribute to the creation of job in production stages of low-volume groups especially of complex products

In conclusion, based on the literature review, it has been found that previous studies have focused more on a descriptive analysis of job creation patterns, based on the measurement of employment growth. In addition, most of the studies regarding job creation are concentrated in countries undergoing the process of economic transition, and are more focused on one technology level group. Therefore, this study has been motivated to analyse the pattern of job creation according to the different technology groups, namely high- and low-technology ones, during the transformation process in the Malaysian manufacturing sector.

In addition to this introduction, the paper comprises five sections. Section 2 presents the data and empirical method employed. The findings of the study are discussed in Section 3, and Section 4 is conclusion.

\section{METHODOLOGY}

The research applies a set of secondary data obtained from the Annual Manufacturing Sector Survey Report released by the Malaysian Department of Statistics. This report is also used as it presents the performance of major indicators of the Malaysian manufacturing sector. The Economic Report released by Bank Negara Malaysia was also employed, aiming to ensure that the data used are accurate.

To analyse the significance of technology in the pattern of job creation, it is important to identify those industries which are technology-intensive or otherwise. According to Hatzichronoglou (1997), firms or industries which are technology-intensive use available resources more effectively and generally offer higher employment. The OECD classification was produced in the United States, and was subsequently applied to all OECD countries. This classification was based on direct $R \& D$ intensity ( $R \& D$ expenditure use direct and indirectly on output) and led to the placement of industries in three categories (high, medium and low technology); it has been used extensively by OECD members as well as other countries. The classification has the advantage of providing a simple and consistent tool for international comparisons. The industrial list is based on the International Standard Industrial Classification, ISIC Rev. 2.

Based on the above explanation, the industrial sector was classified based on the technology level determined by OECD countries. However, the study only focuses on two categories of technology level, namely the high- and low-technology levels. This is because of several limitations, one of which is calculating the job creation rate prior to the study. Analysis of the job creation pattern in the industrial sub-sector was then performed based on the characteristics of job creation, as developed by Davis and Haltiwanger $(1990 ; 1999)$

The graph used to illustrate the pattern of job creation was obtained by plotting the job creation rate calculated prior to the study.

The data obtained were analyzed descriptively. The formula for the sub-sector job creation rate is shown in Equations 1 to 3, based on Davis and Haltiwanger (1999).

The calculation of job creation using the formula introduced is as follows:

Step 1: Calculate the labor change in the sub-sector of the Malaysian manufacturing sector

$$
x_{i t}=\left[\left(E_{i t}+E_{i t-1}\right)\right]
$$


Step 2: Calculate the sector growth of the Malaysian manufacturing sector

$$
g_{s t}=\left[\frac{\left(E_{s t}-E_{s t-1}\right)}{x_{s t}} \times 100\right]
$$

Step 3: Calculate job creation (JC) when the change in the level of labor is divided by sector growth

$$
J C_{s t}=\sum_{+s t} \frac{x_{i t}}{g_{s t}}
$$

where $E$ represents the level of employment; $J C$ represents job creation; $\mathrm{x}_{\mathrm{i}}$ represents the level of employment at the sub-sector level; $X_{s}$ refers to total employment at sector level; $g_{s}$ is sector growth; $t$ is the current year; $s$ is sector; $i$ is sub-sector; and $t-1$ is one year previous to the current year.

\section{RESULTS AND DISCUSSION}

The job creation rate was calculated based on Equation 3, as described in the previous section. The descriptive analysis for the job creation rate in Malaysian high- and low-tech industry from 2005 to 2015 is shown in Table 1. Based on these figures, the minimum job creation rate for high-tech is 0 , while the maximum is 0.60 and the mean is 0.21 . Meanwhile, for low-tech industry, the job creation rate is between 0.02 and 0.26 , with an average rate at 0.09 .

Table 1 Descriptive analysis of job creation for high-tech and low-tech industries

\begin{tabular}{ccccc}
\hline Industry & Minimum & Maximum & Mean & Std. Deviation \\
\hline High-Tech & .00 & .60 & .2148 & .18649 \\
Low-Tech & .02 & .26 & .0973 & .07669 \\
\hline
\end{tabular}

Since the period of the study is 2005 to 2015 , the analysis of job creation is divided into two periods, namely the period before ETP (2005-2010) and that after ETP (2010-2015), as shown in Figures 2 and 3, respectively.

Referring to Figure 2, the high technology (HT) sub-sector exhibited dynamic movement with steady growth from 2007 to 2010. As for the low technology (LT) sub-sector, the pattern of job creation was stable and consistent over the period. There was a substantial fluctuation in the level of job creation every year, and 2009 shows the higher rate of job creation in LT sub-sector even though the economic downturn in that year. The higher job creation rate during the 2009 implies that this sub-sector experienced an increase in demand for labor and job creation. Demand for labor in this sub-sector is expected to continue throughout the year 2009 and not be affected by external shocks, due to its industry features. Most of the industries in this sub-sector have a common feature of producing consumer goods, such as food, beverages and tobacco, wood and furniture, as well as textiles, fabrics, leather apparel and footwear. Therefore, regardless of the economic situation, the demand for production is expected to continue to meet the demands of the population. Hence, employers are expected to continue to create jobs and engage in the production process. In addition, the low technology level of this sub-sector allows firms to offer low skill jobs, leading to more job creation to support the labor-intensive nature of such industries. Another notable pattern was during 2007, when the level of job creation in the low 
technology sector was higher than that of the high technology level, whereas in the preceding year (2006), job creation in high technology exceeded that of low technology.

This circumstance was caused by the rapid transfer of technology in 2006 from foreign investors to drive the economic growth of Malaysia, as well as to encourage firm growth through job creation. It is assumed that the job creation by firms at this time related to high skill jobs to operate the advanced technology in the production processes. However, many job vacancies created were not filled due to the problem of the shortage of highly skilled workers. In 2007, firms shifted from high-skill job creation to that of low-skilled jobs (Economic Annual Report, 2012).

On the other hand, referring to Figure 3, the high technology (HT) sub-sector demonstrated a sharp fall in 2011, before rising in 2012, and then dramatically falling again in 2013. The sharp fall in 2011 indicates that there was zero job creation, albeit zero demand for labor, in this subsector during 2011. This was because the Malaysian government had increased R\&D expenditure in this sub-sector in terms of sophisticated machinery and equipment, with the purpose of upgrading the output of the sub-sector and ensuring smooth production processes (MIDA, 2012).

The sophisticated machinery and equipment required employers to search for highly skilled workers to perform the operation processes. However, highly skilled workers are more expensive than low skilled ones. This will increase the cost of production and reduce the profitability of companies, which will discourage them from engaging in job creation (Klein et al. 2003). This finding also supports that of Elfani and Putra (2013), that more engineers with advanced qualifications and specialized skills are required to fulfil the future needs in the health and medical expertise field.

In addition, the Malaysian government has re-evaluated its policy by focusing on certain key industries in this sub-sector (such as aviation, spacecraft and media and telecommunications equipment). Greater funds have been allocated to R\&D expenditure and to the establishment of several initiatives in these industries to encourage employers to create high skill jobs. One of these initiatives was to set up the Aero-structure Manufacturing Innovation Centre (AMIC), which provides skills training for undertaking the production activities related to aircraft (MIDA, 2012). 


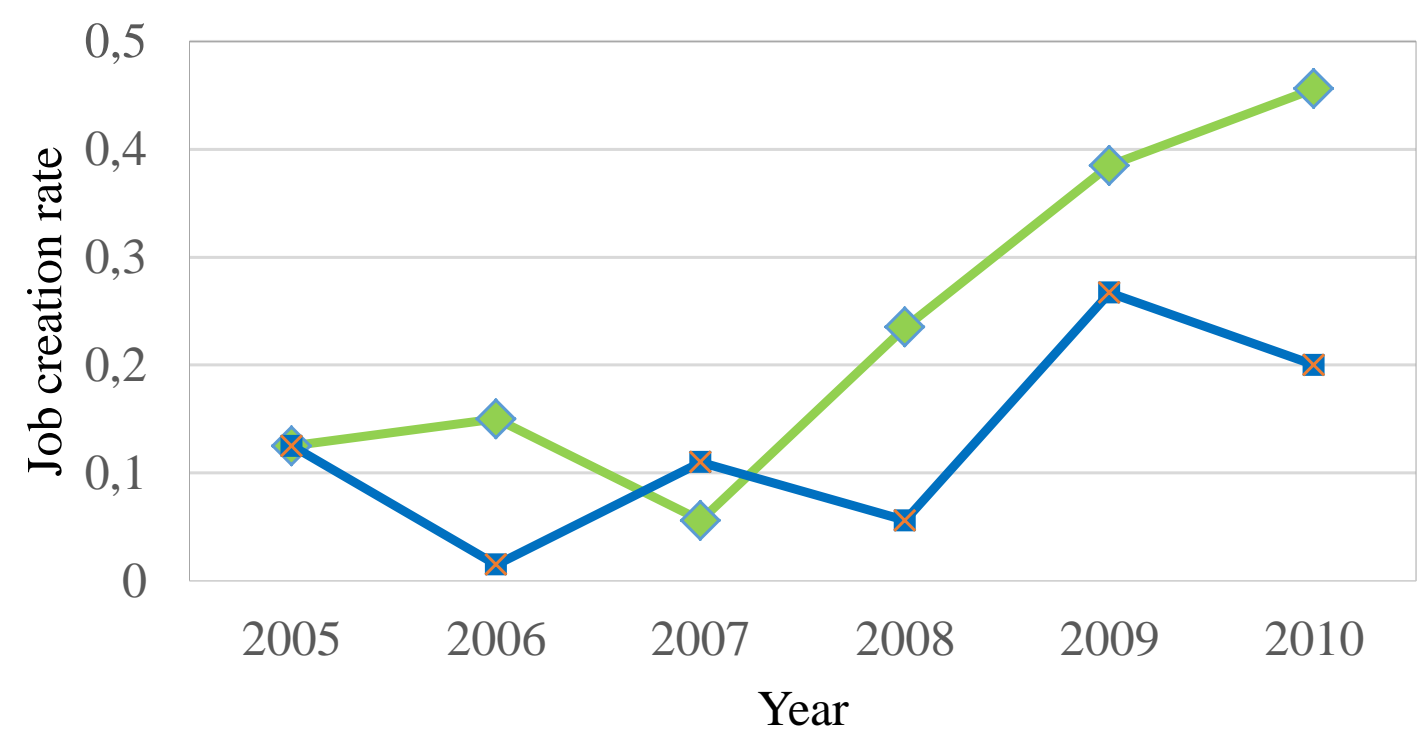

$\checkmark$ High tech $\rightarrow-$ Low tech

Figure 2 Job creation at high- and low-technology levels in the Malaysian manufacturing sector, 2005-2010

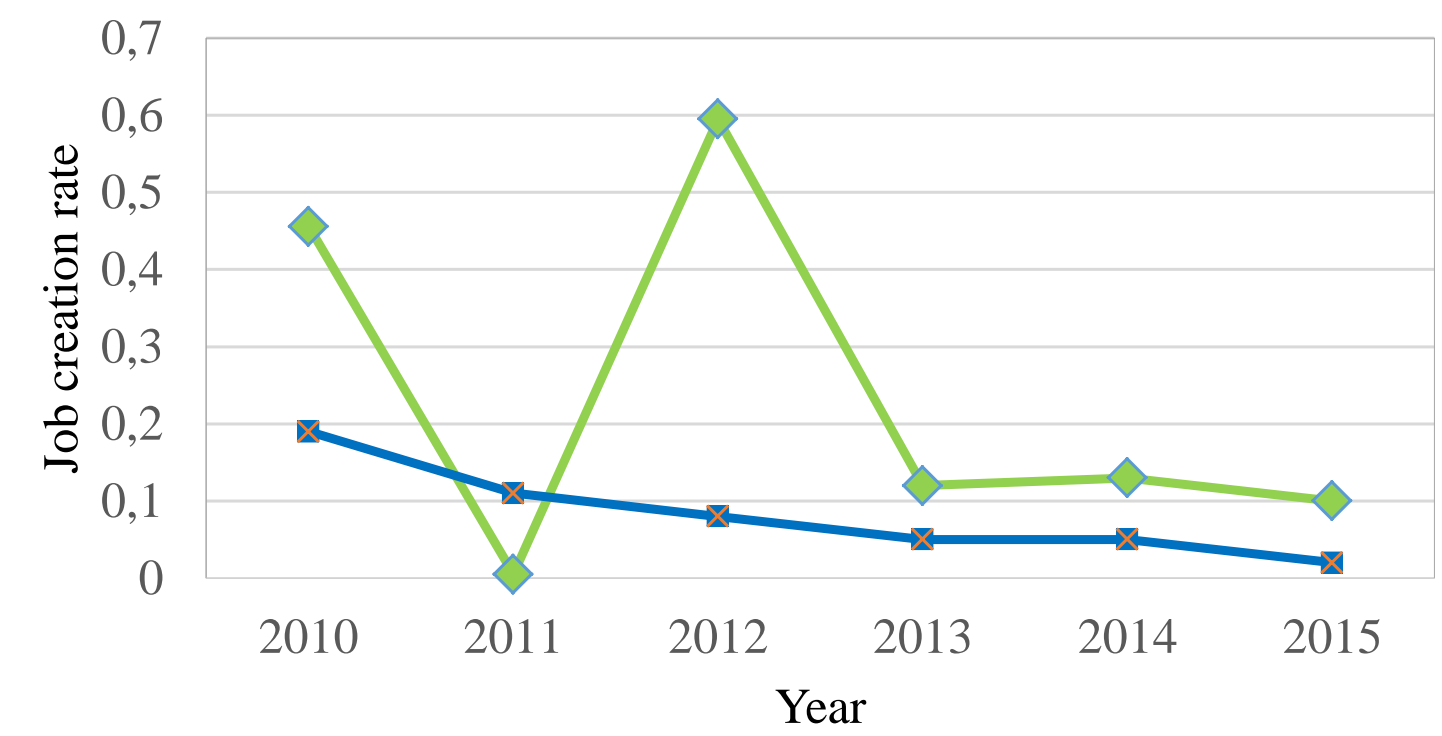

$\checkmark$ High tech $\rightarrow-$ Low tech

Figure 3 Job creation at high- and low-technology levels in the Malaysian manufacturing sector, 2010-2015 
As reported in MIDA (2012), the Malaysian government also increased the incentives for the use of high speed broadband (HSBB) in 2011. This was in line with the goal to transform Malaysia into a high-income country, to create an educated society with knowledge-based production activities. This incentive encouraged consumers to demand media and telecommunication equipment, simultaneously increasing the demand for its production. In response to this demand, employers had to increase their labor force by creating new jobs. Despite the high cost of skilled job creation, employers continue to do this, with the expectation that the gain in profit from the increased production will offset the cost (Cahuc et al., 2014).

As to the findings on the pattern of job creation, it can be summarised that the different technology levels (R\&D expenditure intensity) within the sub-sectors has resulted in different job creation patterns. The higher the technology level, the more dynamic and significant the level of the job creation pattern. However, this higher level in the sub-sectors leads to fluctuations in job creation, as highly skilled workers are very expensive, and so their jobs are replaced by the new technology and advanced equipment. On the other hand, the low technology level subsectors are seen to create stable jobs, as these are labor intensive. The findings also highlight that as Malaysia adopts higher technology and upgrades its R\&D intensity, it will face shortages of highly skilled workers.

\section{CONCLUSION}

This study has found that the job creation pattern for the 11 year study period in the manufacturing sector fluctuated, but was dynamic in nature. For the first time, the study has reported on the job creation pattern in two sub-sectors using the OECD classification of technology. From this analysis method, these two sub-sectors exhibited different patterns in job creation. Notably, the high technology level sub-sector shows the most fluctuating pattern. This is because $R \& D$ expenditure intensity in the manufacturing process is significant from year to year. This pattern influenced the rate of job creation. In the current economic scenario, domestically and globally, the job creation rate is found to be a better and more reliable alternative approach, specifically in the Malaysian manufacturing sector, to measure the performance of the labor market. The important policy of increasing the use of technology will reduce job creation and increase the unemployment rate. The decrease in job creation is due to the limited supply of skilled labor. Therefore, policymakers should attempt to strike a balance between the use of technology and innovation, and job creation capacity. Moreover, it is also can be concluded that in the period before the economic transformation process, that is, from 2005 to 2010, the job creation pattern in the Malaysian high technology manufacturing sector was more stable, while the corresponding pattern in low technology was more dynamic. In contrast, in the period after the transformation program was introduced (2010-2015), the job creation pattern in the high technology industrial sub-sector was more dynamic, whereas in the low technology subsector it was more stable. The findings of the study suggest that the pattern of job creation in both technology level groups is based on the theory of job creation, specifically in the period after the transformation program was introduced (2010-2015).

\section{ACKNOWLEDGEMENT}

This research was supported by the Ministry of Higher Education (MoHE) through the Fundamental Research Grant Scheme (FRGS), S/O Code: 13130. We thank our colleagues from the Research and Innovation Management Centre (RIMC), School of Economics, Finance and Banking (SEFB), and Islamic Business School (IBS), Universiti Uatara Malaysia (UUM), who provided insight and expertise that greatly assisted the research, although they may not agree with all of the interpretations/conclusions of the paper. 


\section{REFERENCES}

Albæk, K., Sørensen, B.E., 1998. Worker Flows and Job Flows in Danish Manufacturing, 198091. The Economic Journal, Volume 108(451), pp. 1750-1771

Blanchflower, D.G., Burgess, S.M., 1996. Job Creation and Job Destruction in Great Britain in the 1980s. ILR Review, Volume 50(1), pp. 17-38

Bogliacino, F., Pianta, M., 2010. Innovation and Employment: A Reinvestigation using Revised Pavitt classes. Research Policy, Volume 39(6), pp. 799-809

Bogliacino, F., Piva, M., Vivarelli, M., 2012. R\&D and Employment: An Application of the LSDVC Estimator using European Microdata. Economics Letters, Volume 116(1), pp. $56-59$

Bogliacino, F., Vivarelli, M., 2012. The Job Creation Effect of R\&D Expenditures. Australian Economic Papers, Volume 51(2), pp. 96-113

Bojnec, Š., Konings, J., 1999. Job Creation, Job Destruction and Labour Demand in Slovenia. Comparative Economic Studies, Volume 41(2-3), pp. 135-149

Cahuc, P., Carcillo, S., Zylberberg, A., 2014. Labor Economic. The MIT Press, Massachusetts, London

Ciriaci, D., Moncada-Paternò-Castello, P., Voigt, P., 2016. Innovation and Job Creation: A Sustainable Relation? Eurasian Business Review, Volume 6(2), pp. 189-213

Coad, A., Rao, R., 2007. Firm Growth and R\&D Expenditure. Economics of Innovation and New Technology, Volume 19(2), pp. 127-145

Davis, S.J., Haltiwanger, J., 1990. Gross Job Creation and Destruction: Microeconomic Evidence and Macroeconomic Implications. NBER Macroeconomics Annual, Volume 5, pp. 123-168

Davis, S.J., Haltiwanger, J., 1992. Gross Job Creation, Gross Job Destruction, and Employment Reallocation. The Quarterly Journal of Economics, Volume 107(3), pp. 819-863

Davis, S.J., Haltiwanger, J.C., Schuh, S., 1998. Job Creation and Destruction. MA and MIT Press Books, Cambridge, London

Davis, S.J., Haltiwanger, J., 1999. Gross Job Flows. Handbook of Labor Economics, Volume 3, Part B, pp. 2711-2805

Elfani M., Putra, N.K., 2013. Biomedical Engineering and Its Potential for Employment in Indonesia. International Journal of Technology, Volume 4(1), pp. 34-44

Faggio, G., Konings, J., 2003. Job Creation, Job Destruction and Employment Growth in Transition Countries in the 90s. Economic Systems, Volume 27(2), pp. 129-154

Garibaldi, P., 1998. Job Flow Dynamics and Firing Restrictions. European Economic Review, Volume 42(2), pp. 245-275

Haltiwanger, J., Vodopivec, M., 2003. Worker Flows, Job Flows and Firm Wage Policies: An Analysis of Slovenia. Economics of Transition, Volume 11(2), pp. 253-290

Hatzichronoglou, T., 1997. Revision of the High-technology Sector and Product Classification. OECD Science, Technology and Industry Working Papers, No. 1997/02

Hijzen, A., Upward, R., Wright, P.W., 2010. Job Creation, Job Destruction and the Role of Small Firms: Firm-level Evidence for the UK. Oxford Bulletin of Economics and Statistics, Volume 72(5), pp. 621-647

Jackson, J.E., Mach, B.W., 2009. Job Creation, Job Destruction, Labour Mobility and Wages in Poland, 1988-1998 1. Economics of Transition, Volume 17(3), pp. 503-530

Kerr, A., Wittenberg, M., Arrow, J., 2014. Job Creation and Destruction in South Africa. South African Journal of Economics, Volume 82(1), pp. 1-18

Kianian, B., Tavassoli, S., Larsson, T.C., 2015. The Role of Additive Manufacturing Technology in Job Creation: An Exploratory Case Study of Suppliers of Additive Manufacturing in Sweden. Procedia CIRP, Volume 26, pp. 93-98 
Klein, M.W., Schuh, S., Triest, R.K., 2003. Job Creation, Job Destruction, and the Real Exchange Rate. Journal of International Economics, Volume 59(2), pp. 239-265

Malaysian Investment Development Authority (MIDA), (2012). Malaysia Investment Performance: Investment for Transformation. Available online at http://www.mida.gov.my/env3/uploads/PerformanceReport/2012/MIPR2012_ENG.pdf, Accessed on April 17 $7^{\text {th }}, 2018$

Mitchell, W., Myers, J., Juniper, J., 2006. The Dynamics of Job Creation and Job Destruction in Australia. Australian Journal of Social Issues, Volume 41(2), pp. 247-259

Piva, M., Santarelli, E., Vivarelli, M., 2005. The Skill Bias Effect of Technological and Organisational Change: Evidence and Policy Implications. Research Policy, Volume 34(2), pp. $141-157$

Schumpeter, J.A., 1961. The Theory of Economic Development. $3^{\text {rd }}$ Edition, Oxford University Press, New York

Said, R., Samsi, A., Saini, W.A., 2012. Effects of R\&D Expenditure on Employment Growth: A Dynamic Panel Analysis. In: Proceeding of $3^{\text {rd }}$ International Conference on Business and Economic Research ( $3^{\text {rd }}$ ICBER 2012, Bandung), pp. 889-897

Stavrunova, O., 2001. Determinants of Job Creation and Job Destruction in Ukraine. Master's Thesis, National University of "Kyiv-Mohyla Academ", Ukraine

Van Reenen, J., 1997. Employment and Technological Innovation: Evidence from U.K. Manufacturing Firms. Journal of Labor Economics, Volume 15(2), pp. 255-284 